\title{
PEMODELAN ARSITEKTUR INFORMASI DENGAN MENGGUNAKAN METODE BUSINESS SYSTEM PLANNING
}

\author{
Nanda Jarti \\ Program Studi Teknik Informatika Universitas Putera Batam
}

\begin{abstract}
This thesis dicusses the modeling of architecture design information at CV. Anggi Pratama. $C V$. ANGGI Pratama is one compony engaged in contractor. Business process that acour with interconnected. This business result form of products related to the project and intented for customers.business process that accour at this time still manually so that in making the report takes a long time. It would require a good management so that in making the report take a long time.it would require a good manjement so that the project can process according to plan. For the research was conducted using the method includes defining business objectives, business process, data classed, and information architecture. The result of which will be a implementation prototype modeling architecture to be built to support business project in the CV. Anggi Pratama
\end{abstract}

Keywords: information architecture, modeling company, business system planning

\section{PENDAHULUAN}

Saat ini teknologi dan sistem informasi berkembang semakin pesat. Keduanya merupakan hal yang tidak dapat terpisahkan, baik untuk kalangan organisasi besar, menengah, atau organisasi kecil. Pembangunan sistem yang mengacu pada penerapan teknologi informasi merupakan dasar bagi organisasi untuk berkembang kearah yang lebih baik, efektifitas dan efisien. Kinerja organisasi dengan menerapkan teknologi informasi diharapkan organisasi dapat meningkatkan kemampuan bersaing dengan para pesaing.

Bagi setiap organisasi yang bergerak dalam dunia bisnis, keuntungan merupakan suatu titik yang ingin dicapai. Penerapan formula strategi dalam bersaing akan terus dikelola untuk hasil optimal yang dapat diperoleh perusahaan dalam menjalankan bisnisnya. Demikian pula halnya dengan perusahaan, pemahaman akan definisi dan proses bisnis akan sangat menentukan porsi keberhasilan dari setiap usaha yang dikelola. 
Arsitektur enterprise merupakan kegiatan pengorganisasian data yang dihasilkan oleh organisasi yang kemudian dipergunakan untuk mencapai tujuan proses bisnis yang diwujudkan dalam bentuk model dan gambar serta memiliki komponen utama yaitu arsitektur bisnis, dengan adanya arsitektur enterprise ini membantu perkembangan teknologi informasi dan komunikasi yang semakin kompleks, menuntut hadirnya rancang bangun yang komprehensif. Sedangkan Business System Planning (BSP) merupakan metodologi dengan tahapan utama yang mengacu pada proses bisnis dan aplikasi data, karena apabila organisasi menginginkan suatu pengembangan sistem informasi secara mendasar, harus diawali dengan kejelasan alur proses dan aliran data sehingga dalam pemanfaatannya dapat menyediakan dan memprioritaskan informasi bagi masing-masing bagian dalam organisasi.

Al-Aboud (2011) menggunakan metode BSP untuk perencanaan skenario dan spekulasi tindakan apa yang harus dilakukan di masa depan pada perusahaan. Sedangkan Calhoun dan lederer (1990) menggunakan metode BSP untuk perencanaan sistem informasi yang akan diidentifikasi untuk melanjutkan organisasi dan kinerja sistem informasi yang efektif. Gottschalk dan saether (2001) menggunakan metode BSP untuk perencanaan tahapan bisnis perusahaan yang diklasifikasikan menurut konfigurasi nilai dan era pertumbuhan IS.

CV Anggi Pratama merupakan salah satu perusahaan yang bergerak di bidang kontraktor. Banyak proyek yang ditangani seperti pembuatan jalan, perumahan, rehab bangunan, sumur bor, pengadaan barang, di sini menggunakan teknologi yang manual, penyediaan tenaga kerja yang terbatas, dan pengelolaan manajemen proyek yang masih standard. Proses informasi yang berjalan saat ini masih manual dan menggunakan email sebagai alat komunikasi, untuk itu diperlukan pemodelan arsitektur informasi untuk mempermudah kerja CV tersebut. Maka digunakanlah metode BSP untuk proses pemodelan CV. Anggi pratama. Dengan Penerapan metode BSP diharapkan dapat membantu dalam pemodelan arsitektur enterprise sebagai strategi untuk memenuhi kebutuhan sistem informasi organisasi yang tepat sesuai dengan kebutuhan dan strategi program kerja. Berdasarkan latar belakang di atas maka penulis mengangkat judul "PEMODELAN ARSITEKTUR 
INFORMASI MENGGUNAKAN METODE BSP (Busines System Planning)" Studi kasus: CV. Anggi Pratama.

\section{Perumusan Masalah}

Dari latar belakang masalah yang telah diuraikan di atas, maka dirumuskan beberapa permasalahan sebagai berikut:

1. Bagaimana proses memodelkan arsitektur informasi untuk penggunaan informasi dalam mendukung aktifitas bisnis pada CV. Anggi Pratama?

2. Bagaimana menghasilkan pemodelan arsitektur informasi dalam bentuk implementasi prototype?

\section{Tujuan}

1. Memahami penggunaan Business System Planning dalam menganalisis kebutuhan bisnis SI.

2. Mengembangkan suatu model arsitektur sistem informasi pada CV. Anggi Pratama.

3. Merancang ulang sruktur kerja untuk mencapai sasarn bisnis yang diharapkan dangan melakukan pendefinisian dan penganalisaan kembali proses bisnis.

\section{Manfaat}

1. Terciptanya suatu model sistem perusahaan.

2. Untuk mempermudah pihak CV dalam mengelola perusahaan.

3. Meningkatkan pengetahuan dan pemahaman penulis mengenai membuat pemodelan arsitektur informasi dengan menggunakan metode BSP (Busines system planning). 


\section{KAJIAN PUSTAKA DAN PENGEMBANGAN HIPOTESIS}

\section{Business System Planning (BSP)}

Business system planning adalah suatu pendekatan terstruktur mengenai bagaimana sistem informasi sebaiknya distrukturkan, diintegrasi dan diimplementasikan untuk jangka panjang (IBM, 1981). Konsep dasar Business System Planning dapat dihubungkan dengan tujuan jangka panjang sistem informasi pada organisasi (IBM, 1981):

1. Mendukung tercapainya goals dan objective dari bisnis.

2. Harus sesuai dengan kebutuhan manajemen pada setiap level.

3. Harus menyediakan informasi yang konsisten.

4. Sistem informasi harus mampu beradaptasi terhadap perubahan organisasi dan manajemen.

5. Sistem informasi harus dapat diimplementasikan dalam subsistem-subsistem dengan tetap berada di dalam satu kerangka arsitektur informasi.

Businnes system planning merupakan proses untuk mentranslasikan strategi bisnis menjadi strategi sistem informasi. Strategi sistem informasi yang dihasilkan dapat mendukung organisasi dalam menjalankan bisnis yang sesusai dengan tujuan organisasi, dapat dilihat pada gambar 2.1

Strategi Bisnis

Tujuan misi dan pengembangan strategi objektif
BSP

IS Strategi

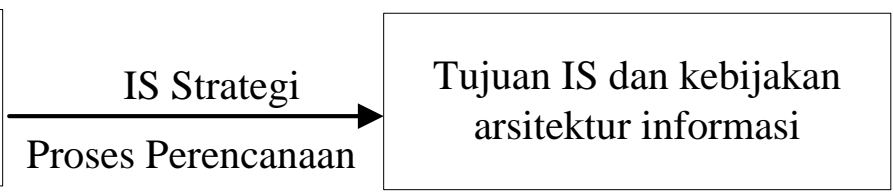

Gambar 2.1 Translasi Strategi Bisnis ke Strategi Sistem Informasi 
Metodologi Business System Planning, terdiri dari lebih banyak langkah yang detail, walaupun begitu dapat digambarkan secara garis besar seperti pada gambar 2.2

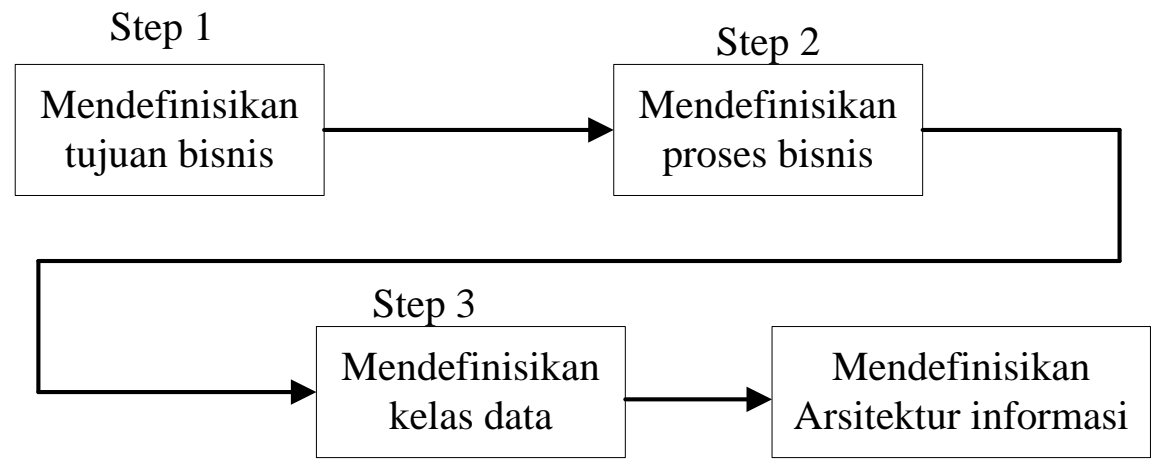

\section{Gambar 2.2 Tahapan Business System Planning}

Langkah 1: Mendefinisikan tujuan bisnis

Untuk memastikan persetujuan semua level eksekutif mengenai arah/tujuan bisnis sehingga strategi sistem informasi dapat mendukung dan akan dibawa secara langsung.

Langkah 2: Mendefinisikan proses bisnis

Menetapkan basis jangka panjang utama bagi sistem informasi dalam mendukung bisnis.

\section{Langkah 3: $\quad$ Mendefinikan kelas data}

Dapat dilakukan berdasarkan proses-proses yang perlu didukung. Kelas data seperti yang tersirat dari nama nya merupakan kategori utama dari data yang diperlukan untuk mendukung satu atau lebih proses bisnis. 


\section{Langkah 4: Mendefinisikan arsitektur informasi}

Menjadi pernyataan tujuan jangka panjang sistem informasi. Biasanya berwujud kelompok area sistem informasi yang saling berhubungan dan diihubungkan dengan data yang akan dikelola. Berdasarkan arsitektur informasi, sebuah modul dapat diidentifikasi, dijadwalkan dan dibangun menurut perencanaan sistem informasi.

Bagian penting dari metodologi Business System Planning adalah rumusan arsitektur informasi, sesuatu yang dapat dibangun dalam modul tetapi menyediakan kembali pertimbangan untuk setiap langkah bisnis. Modul atau bagian yang dapat diimplementasi dikenal sebagai sistem informasi. Masing-masing dapat dianggap sebagai penyimpanan atau titik manjemen untuk himpunan tertentu kelas data. Kelas data yang diimplementasikan, dapat menyediakan kebutuhan informasi berbagai bisnis proses. Masing-masing sistem informasi dihubungkan dengan satu atau lebih proses bisnis dan satu atau lebih kelas data.

Kunci sukses dalam perencanaan, pengembangan dan implementasi arsitektur informasi untuk mendukung tujuan bisnis adalah :

a. Perencanaan secara top-down dengan implementasi secara bottom-up.

b. Mengelola data sebagai sumber daya perusahaan.

c. Orientasi disekitar business proses.

d. Penggunaan metodologi secara menyeluruh.

\section{Mendefinisikan Business Process}

Business proses digambarkan sebagai kelompok-kelompok yang secara logis berhubungan dengan keputusan dan aktifitas yang diperlukan untuk mengelola sumber daya bisnis. Empat tahap siklus hidup produk/layanan dan setiap sumber daya pendukung digunakan untuk mengidentifikasi kelompok proses yaitu :

Tahap 1: Requirement, planning, measurement and control

Aktifitas yang menentukan beberapa banyak produk atau sumber daya diperlukan, rencana untuk mendapatkannya dan pengukuran dan mengontrol lagi rencana tersebut.

Tahap 2: Acquisition or Implementation 
Aktifitas yang performansinya untuk mengembangkan suatu produk/jasa atau untuk mendapatkan sumber daya yang akan digunakan dalam pengembangannya.

Tahap 3: Stewardship

Aktifitas untuk membentuk, meningkatkan, memodifikasi, atau memelihara untuk medukung sumber daya dan untuk menyimpan atau menelusuri produk/jasa.

\section{Tahap 4: Retirement or disposition}

Aktifitas dan keputusan yang mengakhiri tanggung jawab dari suatu organisasi untuk suatu organisasi untuk suatu produk atau jasa atau syarat penggunaan akhir suatu sumber daya.

Tahapan yang diperlukan dalam mendefinisikan proses bisnis dapat dilihat pada gambar 2.3 
ISSN : 2337-8379

Volume 3, Nomor 2, September 2015

Hal :54-69

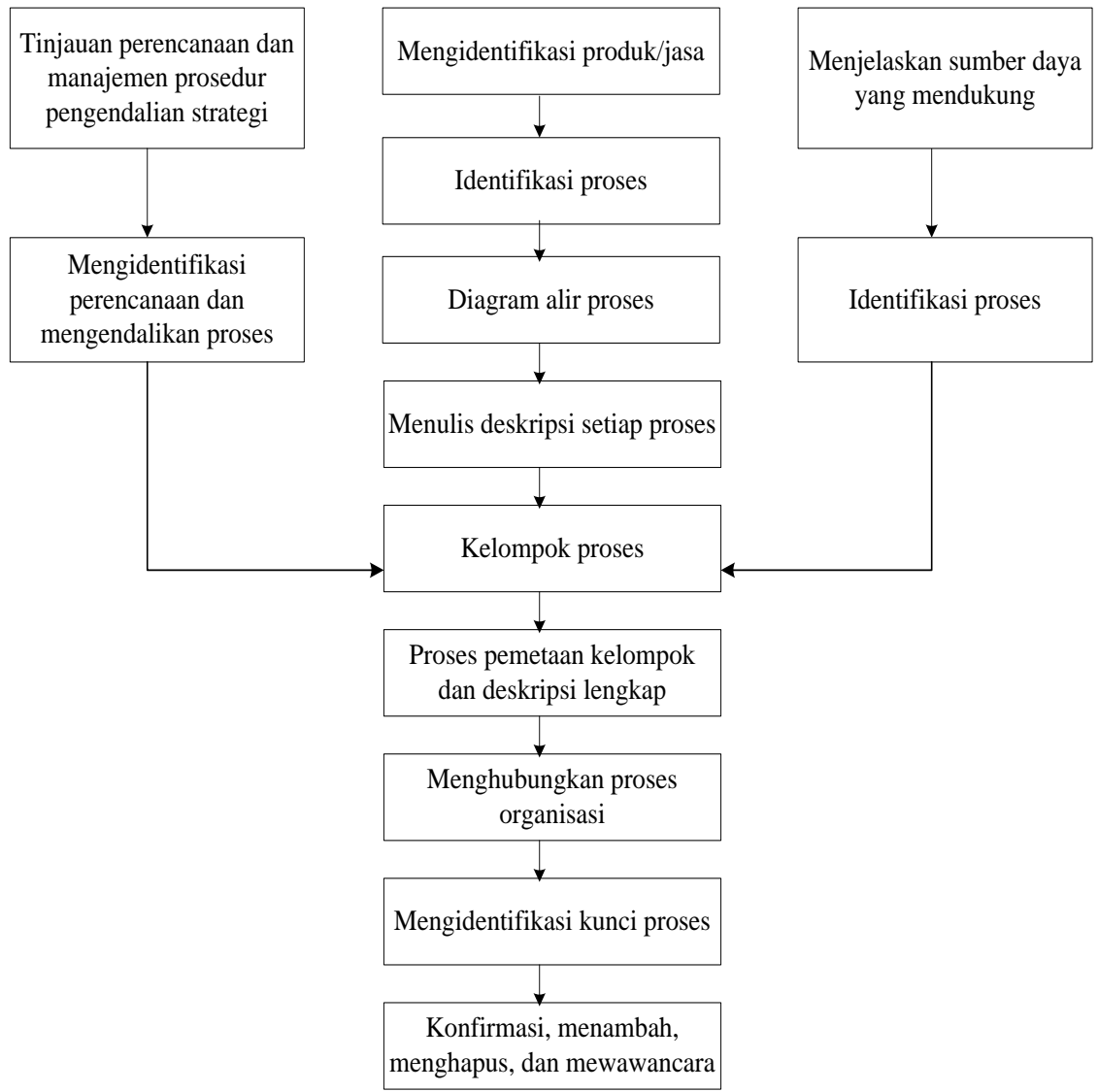




\section{METODE PENELITIAN}

\section{Kerangka Kerja Penelitian}

Pada bagian ini akan diuraikan kerangka kerja dalam rangka penelitian yang akan memandu tahap-tahap pekerjaan yang akan dilakukan agar senantiasa fokus pada tujuan penelitian dan mencapai hasil yang diharapkan dengan waktu yang efisien. Adapun kerangka penelitian diperlihatkan melalui gambar 3.1.

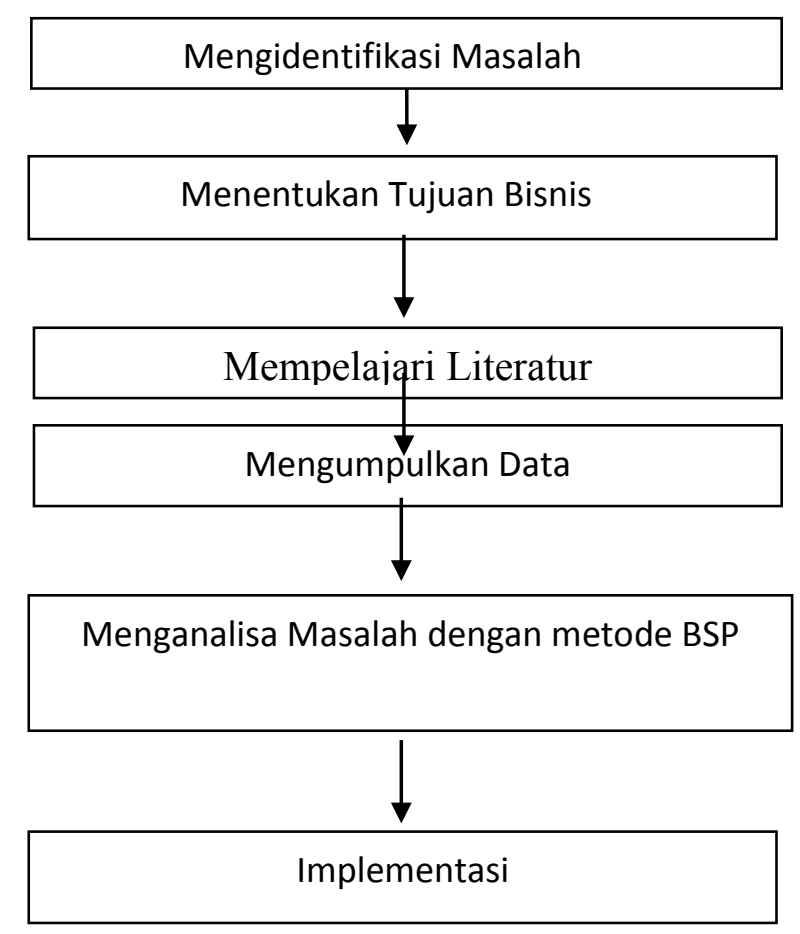

\section{Gambar 3.1 Kerangka Kerja Penelitian}

Selanjutnya akan diuraikan kerangka kerja penelitian berdasarkan gambar 3.1 di atas, yaitu:

\section{Mengidentifikasi Masalah}

Penelitian ini diawali dengan studi literatur, menganalisa dan memodelkan arsitektur informasi yang akan didesain. Untuk membuat kerangka desain perusahaan dengan menggunakan metode Business System Planning, yang mana desain tersebut didasarkan pada hasil analisa pada perusahaan CV.Anggi Pratama.

2. Menentukan Tujuan 
Berdasarkan perumusan masalah yang telah dibuat pada tahap sebelumnya, maka tahap penentuan tujuan berguna untuk memperjelas kerangka tentang apa saja yang menjadi sasaran dari penelitian ini. Pada tahap ini ditentukan tujuan dari penelitian ini adalah bagaimana memodelkan dan mengimplementasikan arsitektur informasi dengan menggunakan metode Busines System Planning

\section{Mempelajari Literatur}

Melalui mempelajari literatur, dipelajari teori-teori yang berhubungan dengan pemodelan arsitektur informasi. Sumbernya berupa buku, jurnal, paper, maupun situs internet yang berhubungan dengan pemodelan arsitektur informasi dan metode Business System Planning

4. Mengumpulkan Data

Dalam pengumpulan data digunakan beberapa metode yang mendukung antara lain :

1. Observasi: yaitu pengumpulan data yang dilakukan dengan cara melakukan pengamatan langsung ditempat penelitian (dalam hal CV. Anggi Pratama).

2. Studi Pustaka: yaitu pengumpulan data dan penelusuran informasi dengan cara membaca dan mempelajari buku-buku dan jurnal-jurnal penelitian yang berkaitan dan menunjang, baik dalam penganalisaan data dan informasi, maupun pemecahan masalah secara keseluruhan.

\section{Menganalisa Masalah Implementasi Metode Bussines Sistem Planning}

Pemilihan metodologi yang digunakan harus disesuaikan dengan kebutuhan organisasi dan permasalahan yang ada, metodologi yang dianggap sesuai dengan hal tersebut adalah metode Bussiness System Planning (BSP), yang memiliki langkah utama sebagai berikut :

1. Mendefinisikan Tujuan Bisnis.

2. Mendefinisikan Proses Bisnis.

3. Mendefinisikan Kelas Data.

4. Mendefinisikan Arsitektur Informasi.

6. Implementasi 
Setelah mengolah data menggunakan metode Bussiness Sistem Planning untuk memperkirakan bentuk pemodelan arsitektur informasi, maka dibuatlah prototype sistem informasi dengan menggunakan laptop dengan spesifikasi perangkat keras dan perangkat lunak sebagai berikut :
a. Processor : intel (R) Core(TM) i5-4200U CPU @ 1.60G Hz 2.30GHz
b. Memory : $4 G B D D R 3$
c. VGA : NVDIA GeForce GT740-2GB
d. Hardisk : 750 GB serial ATA 5400 RPM

\section{ANALISA DAN PERANCANGAN}

\section{Analisa Masalah}

Analisa pada tahap ini dilakukan berdasarkan masalah yang ada pada $\mathrm{CV}$. Anggia Pratama. Akan dilakukan beberapa tahap pemodelan arsitektur informasi dengan menggunakan metode Business System Planning. Berdasarkan literatur yang ada dan observasi langsung kelapangan, terdapat beberapa masalah pada proyek, keuangan proyek, dan manajemen. Untuk memperjelas proses analisa pemodelan sistem di masa yang akan datang, maka pada tahap ini analisa dilakukan dengan mengikuti metode Business System Planning yang memiliki tahapan-tahapan sebagai berikut :

1. Mendefinisikan tujuan bisnis

2. Mendefinisikan Business Process (proses bisnis)

3. Mendefinisikan kelas data.

4. Mendefinisikan arsitektur informasi.

\section{Perencanaan dan Pengendalian Proses}

Dalam tahap ini dilakukan pengumpulan informasi tentang perencanaan, faktor sukses dari CV. Anggi Pratama yang dikelompokkan kedalam perencanaan strategi dan manajemen kontrol. Perencanaan strategi adalah perencanaan untuk jangka panjang dan manajemen kontrol adalah untuk mengontrol dari kegiatan operasional. 
Dalam menjalankan strategi perencanaan dan pengendalian proses dari CV. Anggi Pratama dapat dilihat pada tabel 4.1

Tabel 4.1 Perencanaan Strategi dan Manajemen Kontrol

\begin{tabular}{|l|l|}
\hline Perencanaan strategi & Manajemen Kontrol \\
\hline Pengembangan organisasi & $\begin{array}{l}\text { Meningkatkan kualitas organisasi } \\
\text { (level perusahaan) }\end{array}$ \\
\hline Pengembangan kebijakan & $\begin{array}{l}\text { Peningkatan kualitas kinerja dan } \\
\text { menawarkan produk baru }\end{array}$ \\
\hline Mengembangkan kerja sama & $\begin{array}{l}\text { Memperluas hubungan dengan pihak } \\
\text { yang terkait }\end{array}$ \\
\hline
\end{tabular}

Adapun tahapan selanjutnya dalam proses bisnis pada CV.Anggi Pratama adalah menganalisa produk yang akan dihasilkan oleh CV. Anggi Pratama. Dalam hal ini juga menganalisa proses-proses yang akan dibutuhkan dalam menghasilkan sebuah produk. Untuk menghasilkan produk tersebut dapat dilakukan dengan tahapan-tahapan sebagai berikut:

1. Produk dari CV. Anggi Pratama

CV. Anggi pratama merupakan suatu enterprise yang menghasilkan produk yang bersifat usaha dan berhubungan dengan proyek. Produk tersebut adalah layanan meningkatkan kepercayaan client proyek kepada perusahaan. Produk layanan tersebut berupa pembuatan jalan, rehab bangunan, dan sumur bor.

2. Tahapan siklus hidup proses layanan

Tahapan ini dilakukan untuk mengidentifikasi proses layanan dengan melihat dari kebutuhan yang akan diproses, sehingga menghasilkan layanan kepada client. Setiap proses layanan memiliki siklus hidup tersendiri 
Tabel 4.2 Tahapan Siklus Hidup Proses Produksi

\begin{tabular}{|l|l|l|l|}
\hline Layanan & Penerimaan & Proses layanan & Hasil \\
\hline Proyek & Kerja sama proyek & $\begin{array}{l}\text { Perencanaan } \\
\text { proyek }\end{array}$ & $\begin{array}{l}\text { Laporan } \\
\text { proyek }\end{array}$ \\
\hline Keuangan & $\begin{array}{l}\text { Penerimaan dana } \\
\text { proyek }\end{array}$ & $\begin{array}{l}\text { Penawaran } \\
\text { proyek }\end{array}$ & Lap keuangan \\
\hline Manajeman & $\begin{array}{l}\text { Pembentukan Tim } \\
\text { proyek, pengawas } \\
\text { proyek }\end{array}$ & $\begin{array}{l}\text { Koordinasi sistem } \\
\text { kerja }\end{array}$ & Tim proyek \\
\hline
\end{tabular}

3. General flowchart dari Proses produk

Setelah proses kegiatan yang terjadi didalam CV.Anggi Pratama diidentifikasi, selanjutnya membuat general flowchart sehingga dapat diketahui hubungan antara bisnis proses tersebut. Dalam membuat general flowchart digunakan proses bisnis yang ada di table 4.2. 

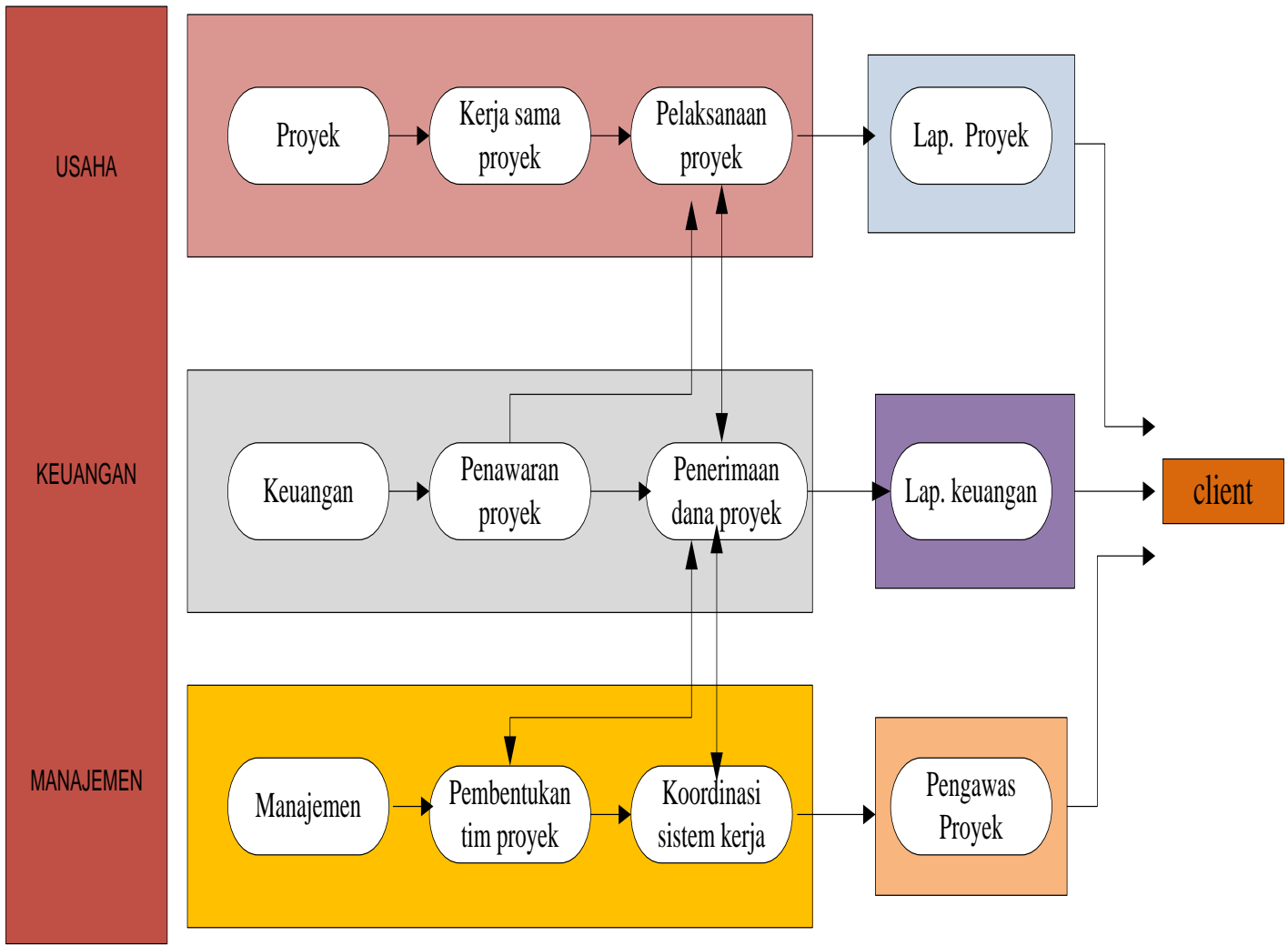

Gambar 4.2 General Flowchart

Deskripsi Setiap Proses Pada General Flowchart

A. Usaha.

1. Proyek.

Proyek berupa kegiatan usaha yang dilakukan oleh CV. Anggi Pratama dan nantinya menghasilkan suatu produk hasil kerja. Proyek yang dimaksud seperti pengerjaan jalan, sumur bor, pembangunan, dan rehap bangunan.

2. Kerjasama Proyek.

Bentuk kegiatan dimana terdapat kesepakatan antara pihak client dan CV.Anggi Pratama didalam mengerjakan suatu proyek. Hal-hal yang termasuk didalam kerjasama proyek meliputi kesepakatan waktu kerja, 
aturan pekerjaan, sanksi dan kewajiban kedua belah pihak, dan hal-hal penting lainnya terkait pengerjaan proyek.

3. Pelaksanaan proyek.

Pelaksanaan proyek adalah proses penyelesaian kerja proyek yang telah diberikan ke CV.anggi pratama. pelaksanaan proyek meliputi seluruh kegiatan didalam pengerjaan proyek dari awal sampai akhir.

4. Laporan proyek.

Laporan proyek adalah bentuk laporan dari kegiatan pelaksanaan proyek yang sudah dilaksanakan oleh CV. Anggi Pratama. dimana laporan proyek ini juga nantinya akan sebagai informasi terkait pelaksanaan proyek kepada client.

B. Keuangan.

1. Keuangan proyek

Keuangan proyek adalah proses keuangan yang terjadi terkait program yang sedang dikerjakan oleh CV. Anggi Pratama. Keuangan proyek berisi data semua kebutuhan keuangan dan aliran dana selama pelaksanaan proyek. Keuangan proyek berasal dari dana yang diberikan pemberi proyek atau client.

2. Penerimaan dana proyek

Peneraimaan dana proyek adalah sumber dana kegiatan proyek yang diberikan oleh client dimana client proyek cv.anggi paratama adalah dari pemerintah.

3. Penawaran proyek.

Penawaran proyek adalah proses dimana CV. Anggi pratama mengajukan rancangan kerjanya untuk menyelesaikan suatu pekerjaan proyek. Penawaran proyek meliputi harga penawaran didalam proyek yang diajukan oleh cv.anggi pratama terhadap harga yang telah ditetapkan oleh clinet. penawaran proyek juga rincian perencanaan proyek yang akan dilakukan selama proyek nantinya dikerjakan. 
4. Laporan keuangan proyek.

Laporan keuangan proyek adalah bentuk laporan pengelolaan aliran dana modal proyek yang diberikan oleh client untuk kepentingan penyelesaian proyek. Laporan keuangan proyek juga terkait dengan penawaran proyek yang diajukan oleh cv.anggi pratama dan disetujui oleh client. Laporan keuangan proyek nantinya akan sebagai informasi keuangan untuk client dalam melihat pengelolaan dana yang telah diberikan.

C. Manajemen

1. Manajement proyek.

Adalah proses manajement didalam proyek yang dikerjakan. Manajement proyek meliputi struktur kerja proyek dan orang-orang yang terlibat didalam pengerjaan proyek.

2. Pembentukan tim proyek

Proses pembentukan struktur tim yang akan mengerjaka proyek nantinya. Tim yang akan dibentukan adalah kumpulan dari orang-orang yang mempunyai kemampuan didalam pengerjaan proyek yang akan dikerjakan. Pembentukan tim proyek dilakukan hanya pada setiap proyek yang dikerjakan. Antara proyek satu dengan proyek lainnya memiliki tim yang berbeda, karena tim proyek dibuat berdasarkan seperti apa kebutuhan dari proyek tersebut. Posisi tertinggi didalam tim proyek nantinya pada posisi pelaksana proyek dan mandor.

3. Koordinasi sistem kerja.

Koordinasi sistem kerja adalah proses koordinasi kerja antara tim proyek dengan pengawas proyek. Di mana terjadi penyampaian informasi terkait tentang tanggung jawab dan tugas masing-masing dari tim proyek dan pengawas proyek. Selain tugas dan tanggung jawab informasi lain adalah terkait permasalahan yang terjadi selama proses pengerjaan proyek dan kebijakan-kebijakan untuk mendukung pengerjaan proyek.

\section{Pengawas proyek}


Pengawas proyek adalah proses untuk mengawasi kinerja proyek yang dilakukan oleh CV. Anggi Pratama, untuk menjaga agar pengerjaan proyek yang sedang dilakukan sesuai dengan aturan yang berlaku sehingga hasilnya sesuai yang diharapkan.

\begin{tabular}{|c|c|c|c|c|c|c|c|c|c|c|c|c|c|c|}
\hline Kelas Data & 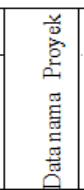 & 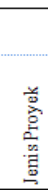 & 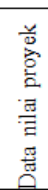 & 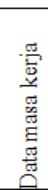 & 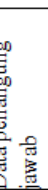 & 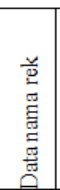 & 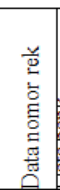 & 鹿 & 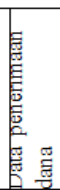 & 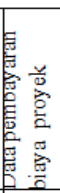 & 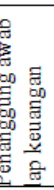 & & 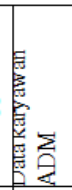 & 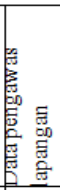 \\
\hline Perencanaan proyek & $\mathrm{Y}$ & $\mathrm{Y}$ & $\mathrm{Y}$ & $\mathrm{Y}$ & $\mathrm{Y}$ & & & & $\mathrm{Y}$ & $\mathrm{x}$ & & $\mathrm{x}$ & & \\
\hline Kegitan proyek & $\mathrm{Y}$ & $\mathrm{Y}$ & $\mathrm{x}$ & $\mathrm{Y}$ & $\mathrm{Y}$ & & & & $\mathrm{Y}$ & $\mathrm{x}$ & & $\mathrm{Y}$ & & $\mathrm{Y}$ \\
\hline Laporan proyek & $\mathrm{x}$ & $\mathrm{x}$ & $\mathrm{x}$ & $\mathrm{Y}$ & $\mathrm{Y}$ & & & & $\mathrm{Y}$ & $\mathrm{x}$ & & $\mathrm{Y}$ & & $\mathrm{Y}$ \\
\hline Kerja sama proyek & $\mathrm{Y}$ & $\mathrm{x}$ & $\mathrm{Y}$ & $\mathrm{x}$ & $\mathrm{Y}$ & $\mathrm{Y}$ & $\mathrm{Y}$ & & $\mathrm{Y}$ & & & & & \\
\hline Penawaran proyek & $\mathrm{Y}$ & $\mathrm{x}$ & $\mathrm{Y}$ & $\mathrm{x}$ & $\mathrm{Y}$ & Y & $\mathrm{Y}$ & $\mathrm{Y}$ & $\mathrm{x}$ & $\mathrm{Y}$ & $\mathrm{Y}$ & $\mathrm{Y}$ & & \\
\hline Penerimaan dana proyek & $\mathrm{Y}$ & & $\mathrm{Y}$ & $\mathrm{Y}$ & $\mathrm{Y}$ & $\mathrm{Y}$ & $\mathrm{Y}$ & & $\mathrm{x}$ & $\mathrm{x}$ & $\mathrm{Y}$ & & & \\
\hline Pelaksana proyek & $\mathrm{Y}$ & $\mathrm{Y}$ & $\mathrm{x}$ & $\mathrm{x}$ & $\mathrm{Y}$ & & & & $\mathrm{Y}$ & $\mathrm{Y}$ & $\mathrm{Y}$ & $\mathrm{Y}$ & & $\mathrm{Y}$ \\
\hline Lap.keuangan proyek & $\mathrm{Y}$ & & & & $\mathrm{Y}$ & $\mathrm{Y}$ & $\mathrm{Y}$ & & $\mathrm{Y}$ & $\mathrm{Y}$ & $\mathrm{x}$ & & & \\
\hline Pembentukan tim proyek & $\mathrm{Y}$ & $\mathrm{Y}$ & & $\mathrm{x}$ & $\mathrm{x}$ & & & & & & & $\mathrm{x}$ & & \\
\hline Koordinasi sistem kerja & $\mathrm{Y}$ & $\mathrm{Y}$ & $\mathrm{Y}$ & $\mathrm{x}$ & $\mathrm{Y}$ & & & & $\mathrm{Y}$ & $\mathrm{Y}$ & & $\mathrm{Y}$ & & $\mathrm{Y}$ \\
\hline Pengawas proyek & $\mathrm{Y}$ & $\mathrm{Y}$ & $\mathrm{Y}$ & $\mathrm{x}$ & $\mathrm{Y}$ & & & & & & & $\mathrm{Y}$ & $\mathrm{Y}$ & \\
\hline
\end{tabular}

1. Perencanaan proyek menggunakan data nama proyek, jenis proyek, nilai proyek, masa kerja, penanggung jawab, dan data penerimaan dana, untuk melakukan kegiatan proyek yang akan dilaksanakan. Dan menghasilkan data pembayaran biaya proyek, dan data anggota dalam proses bisnisnya.

2. Kegiatan proyek menggunakan data nama proyek, jenis proyek, masa kerja, penanggung jawab, penerimaan dana, data anggota dan dan data pengawas lapangan untuk melangsung kan pelaksanaan kegiatan yang akan dilakukan dan menghasilkan data nilai proyek, dan data pembiayaran proyek dalam proses bisnisnya.

3. Laporan proyek menghasilkan data nama proyek, jenis proyek, nilai proyek, dan pembayaran biaya proyek dalam proses bisnisnya dan 
menggunakan kelas data masa kerja, penanngung jawab, penerimaan dana, data anggota, dan data pengawas lapangan dalam proses pelaksanaannya.

4. Kerja sama proyek menggunakan data nama proyek, data nilai proyek, data penanggung jawab, nomor rekening, nama rekening, dan data penerimaan dana dalam proses bisnisnya.

5. Penawaran proyek menggunakan data nama proyek, data nilai proyek, data penanggung jawab, data nama rekening, data no, rekening, data bank penjamin, data pembayaran biaya proyek, data penanggung jawab laporan keuangan, dan data anggota untuk proses bisnisnya dan menghasilkan data jenis proyek, data masa kerja, dan data penerimaan dana untuk proses bisnisnya.

6. Penerimaan dana proyek menggunakan data nama proyek, data nilai proyek, data masa kerja, data penanggung jawab, data nama rekening, data no rekening, dan menghasilkan data penerimaan dana dan data pembayaran biaya proyek dalam proses bisnisnya.

7. Pelaksanaan proyek menggunakan data nama proyek, data jenis proyek, data penanggung jawab, data penerimaan dana, data pembayaran biaya proyek, data penanggung jawab laporan keuangan, data anggota, data pengawas lapangan dan menghasilkan data nilai proyek serta data masa kerja untuk proses bisnisnya.

8. Laporan keuangan proyek menggunakan data nama proyek, data penaggung jawab, data nama rekening, data no rekening, data penerimaan dana, data pembayaran biaya proyek dan menghasilkan data penanggung jawab laporan keuangan untuk proses bisnisnya.

9. Pembentukan tim proyek menggunakan data nama proyek, data jenis proyek, dan menghasilkan data masa kerja, data penanggung jawab dan data anggota untuk proses bisnisnya.

10. Koordinasi sistem kerja menggunakan data nama proyek, data jenis proyek, data nilai proyek, data penanggung jawab, data penerimaan dana, data pembayaran biaya proyek, data anggota, data pengawas lapangan, dan menghasilkan data masa kerja proyek untuk proses bisnisnya. 
11. Pengawas proyek menggunakan data nama proyek, data jenis proyek, data nilai proyek, data penanggung jawab, data anggota, data karyawan ADM dan menghasilkan data masa kerja untuk proses bisnisnya.

\section{Mendefinisikan Arsitektur Informasi}

Dalam menentukan arsitektur informasi pada hubungan kelas data dengan proses pemodelan arsitektur informasi CV. Anggi Pratama, dilakukan proses-proses sebagai berikut:

1. Area Proses dan Kelompok Kelas Data.

Berdasarkan fungsinya, proses pengelompokkan kelas data dan proses bisnis dapat dilihat pada Tabel 4.10.

2. Identifikasi Aliran Data.

Identifikasi aliran data digunakan untuk menggambarkan aliran dari daerah sistem ke sistem lainnya. Dapat dilihat pada Tabel 4.11.

3. Arsitektur Informasi.

Dengan menggunakan symbol-simbol dalam menandai penggunaan yang kemudian diberi nama untuk masing-masing wilayah sistem utama. Simbol tersebut adalah simbol kotak dan panah, penempatan dari simbol-simbol tersebut dapat dilihat pada Tabel 4.12.

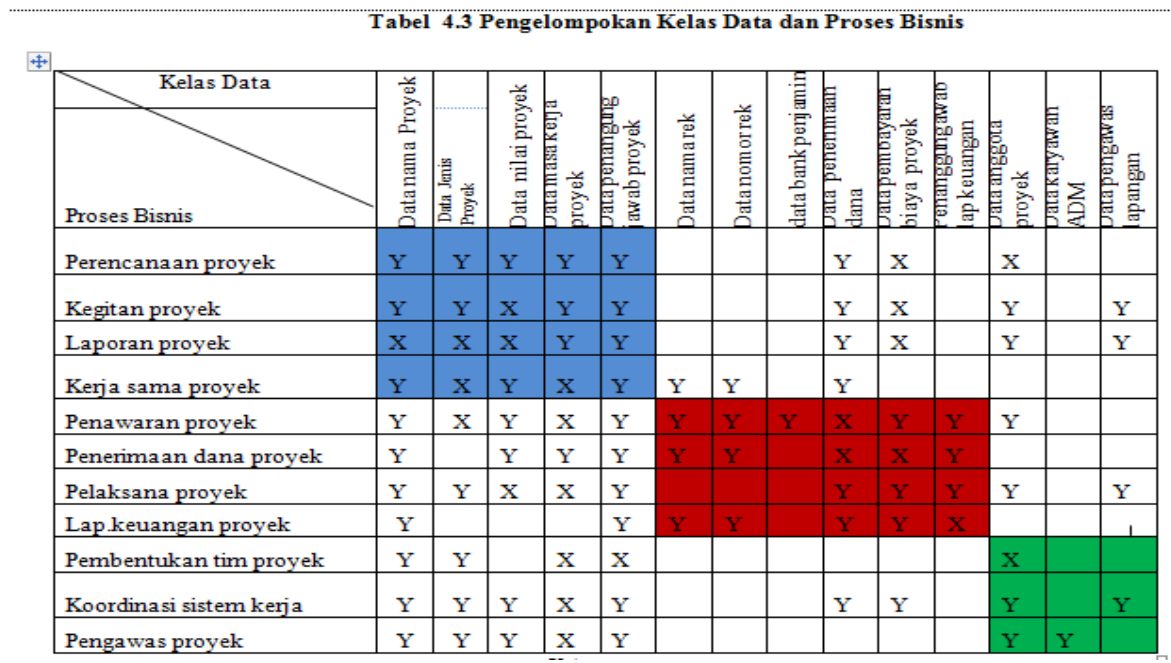




\section{V.SIMPULAN}

Berdasarkan dari hasil penelitian yang dilakukan di CV.Anggi Pratama maka dapat disimpulkan :

1. Berdasarkan analisa yang telah dilakukan, diperoleh suatu pemodelan arsitektur informasi prototype di CV. Anggi Pratama

2. Berdasarkan pendefinisian kelas-kelas data, maka diperoleh 14 kelas data yang kemudian dilakukan pendefinisian kelas data dan hubungan dengan proses bisnis yang ada pada CV. Anggi Pratama.

3. Berdasarkan pendefinisian arsitektur informasi maka diperoleh area antara proses dengan kelompok kelas data serta arsitektur informasi dalam persepsi proses bisnis dan kelas data.

4. Dengan adanya arsitektur informasi memberikan kemudahan dalam mengembangkan sistem informasi yang akan dibangun.

\section{Saran}

Berdasarkan kesimpulan di atas maka dapat diberi saran-saran sebagai berikut:

1. Hendaknya setiap organisasi mendokumentasikan pemodelan sistem informasi secara matang dan mendasar.

2. sistem informasi yang terintegrasi merupakan hal mendasar yang harus dikembangkan, agar data selalu tersedia bagi pihak manajerial dan memudahkan pula dalam hal pengelolaannya.

3. penelitian pemodelan arsitektur informasi prototype yang dibuat memiliki peluang pengembangan yang besar dimasa yang akan datang. 


\section{DAFTAR PUSTAKA}

Azhar susanto (2000), sistem informasi manajemen, Andi Offset

Bernard Boar (2001), the art of strategic planning for information technology second edition, willey computer publishing, 1-42

CJ. Date (2000), An introduction to Database system, Addison Wesley longman, Inc , 2-56

Cook malissa A (1996), Building enterprise information architectur, printice Hall PTR, 1179

Hall James , A (2001), System informasi akuntansi, Salemba Empat, 5-489

IBM Corporation, Business system palnning, 1- 161

Nugroho widjajanto , sistem informasi akuntansi , Erlangga,13-30 